Original Research

\title{
Therapy of Brain Exercise on The Quality of Sleeping in Elderly
}

\author{
Ita Irvana ${ }^{1}$, Galia Wardha Alvita1 ${ }^{1}$, Icca Narayani Pramudaningsih ${ }^{2}$, Vera Fitriana ${ }^{2}$
}

1 STIKES Cendekia Utama Kudus, Indonesia

2 AKPER Krida Husada Kudus, Indonesia

\section{Article Info}

Article History:
Submit July 15th, 2020
Accepted Sept 5th, 2020
Published Sept 30th 2020
Keywords:
Brain Gym; Sleep Quality;
Elderly

\section{INTRODUCTION}

Aging is a natural process that cannot be avoided with age. Even though it is a natural thing, the process of aging still causes problems both physically, biologically, mentally and socio-economically due to a decline which is called a degenerative process The process of degeneration that occurs in the elderly, causes time. Effective sleep will decrease so that adequate quality of sleep is not achieved and will cause various kinds of sleep complaints or sleep

\section{Abstract}

The aging is a natural process that cannot be avoided with age. Even though it is a natural thing, the process of aging still causes problems both physically, biologically, mentally and socio-economically due to a decline which is called a degenerative process The process of degeneration that occurs in the elderly, causes time. World Health Organization (WHO) confirmed that there were 600 million elderly people in 2012 worldwide. WHO also noted that there are 142 million elderly people in the Southeast Asia region. Meanwhile, according to the Central Statistics Agency (BPS), it was noted that the number of elderly people in Indonesia reached 28 million in 2012 from only 19 million in 2006. The results of the data recapitulation of the Central Java health office recorded 3 million elderly people in Central Java. The method in this study was experimental research and quasiexperimental design type with quasi-experimental design and village control group. Sample determination using the Total Sampling technique with a sample size of 30 respondents. Data analysis was performed using the Wilcoxon test. The results obtained before being given an intervention that has a level of good sleep quality amounted to $43.3 \%$ and after given an intervention that has a level of quality of sleep that is good, the minimum is $76.7 \%$. Statistically obtained a p-value of $0,000(<0.05)$ can be interpreted that there is a significant influence on brain gymnastics on the quality of sleep in the elderly.

Corresponding author:

Ita Irvana

itairvana99@gmail.com

South East Asia Nursing Research, Vol 2 No 3, September 2020

ISSN:2685-032X

DOI: $\underline{\text { https://doi.org/10.26714/seanr.2.3.2020.1-6 }}$

disturbances. ${ }^{1}$ The disturbance of sleep patterns causes suffering for the elderly because it reduces the quality of life so that it needs attention from health workers. The approach in managing sleep disorders must be systematic and comprehensive both physically and mentally, not only medical drugs but complementary therapies need to be developed by training the elderly to relax their thoughts before going to sleep such as taking deep breaths, reading books, using aromatherapy, or using aromatherapy. brain exercise therapy. ${ }^{2}$ 
Sleep problems faced by the elderly can be used as a reference for providing appropriate nursing interventions in overcoming problems related to sleep fulfilment. Physical exercise is proven to increase the fulfilment of sleep needs in the elderly because it can get relaxation, improve blood circulation, and can reduce stress. $^{3}$ World Health Organization (WHO) confirmed that there were 600 million elderly people in 2012 worldwide. WHO also noted that there are 142 million elderly people in the Southeast Asia region. Meanwhile, according to the Central Statistics Agency (BPS), it was noted that the number of elderly people in Indonesia reached 28 million in 2012 from only 19 million in 2006. The results of the data recapitulation of the Central Java health office recorded 3 million elderly people in Central Java. This figure shows an increase in the number of elderly people by $22.5 \%$ from 2,323,541 in 2010. Quantitatively, this parameter is higher than the national size. Data from the Central Statistics Agency show that the number of elderly people over 60 years of age in Central Java Province has experienced an increase in life expectancy.

The increase in the elderly in the coming year can bring new social problems if the elderly is the responsibility of the population of productive age in the future. In 2014 the number of elderly people reached 3.83 million people or 11.43 per cent of the total population of Central Java Province then increased to 3.96 million people or $11.72 \%$ in 2015. Meanwhile, based on the results of the Projection Figures 18 Profile of the Elderly in Central Java 2018 Population in 2018, the number of elderly people in Central Java Province increased to 4.49 million people or $13.03 \%{ }^{4}$

Changes in sleep patterns in the elderly can result in changes in the neurological system which can decrease the number and size of neurons in the central nervous system. Changes in sleep can affect sleep quality related to the aging process such as increased sleep latency, waking early can reduce the stages of deep sleep. To overcome sleep disorders in the elderly it is necessary to carry out non-pharmacological therapies such as brain exercise. Brain gym or brain exercise is a simple movement that uses the brain as a whole. Brain exercise is Educational Kinesiology which means "Educare " (pulling out) and "Kinesis" (the study of body movements). So that with brain exercise, we can draw out the potential that is buried in us through body movements.

Based on the results of preliminary studies on elderly social care homes Potroyudan Jepara on the 29th of January 2020, there are 30 elderly who live in nursing, a male total of 11 elderly and female amounted to 19 elderly people with an average age above 60 years. Based on interviews conducted by researchers with 10 respondents, 4 people said they were often sleepy in the morning because they often wake up at night and have difficulty sleeping again. Meanwhile, as many as 6 people complained of going to bed early and waking up again at midnight. Based on this reason, the authors are interested in knowing the quality of sleep for the elderly in the Potroyudan Jepara elderly social centre.

\section{METHODS}

The type in this research is quasiexperimental or quasi-experimental with one group pretest and posttest. The population in this study were elderly patients who experienced quality sleep in Potroyudan Social Service Institutions in Jepara. Where the population is 30 people. There is also a total sample size of 30 samples and the determination of the sample using the Total Sampling technique. The inclusion criteria in this study were elderly people aged 50 years and above. The elderly with poor sleep quality are taking sleeping pills. The exclusion criteria were the elderly outside the Potroyudan social service institutions in Jepara. The elderly who do not have problems with sleep disorders are not willing to be 
respondents. Elderly who have chronic diseases. The location of this research was located at the Potroyudan Social Service Home in Jepara in July 2020. Instrument of research is using SOP gymnastics Brain and observation sheets and questionnaires PSQI. The results of this study used the Wilcoxon test statistical test.

\section{RESULTS}

Based on table 1, the results show that the age of most respondents is 66-80 years old, with 18 respondents with a percentage of $60.0 \%$, followed by 50-65 years of age, whose respondents were 19 people with a percentage of $40.0 \%$. The number of men was 12 people ( $40.0 \%$ ) and female were 18 people (60.0\%).

Table 1

Frequency Distribution based on Age of elderly respondents at the Potroyudan Social Institution in Jepara in July $2020(n=30)$

\begin{tabular}{lll}
\hline Indicators & $\mathrm{f}$ & $\%$ \\
\hline Age & & \\
$50-65$ & 12 & 40.0 \\
$66-80$ & 18 & 60.0 \\
\hline Sex & & \\
$\quad$ Male & 12 & 40.0 \\
$\quad$ Female & 18 & 60.0 \\
\hline
\end{tabular}

Based on table 2, before giving the intervention, there were 13 people with a good sleep quality level with a percentage of $43.3 \%$ and 17 people who had a bad sleep quality level with a percentage of $56.7 \%$. Whereas in the category after giving the intervention, there were 23 people with a good sleep quality level with a percentage of $76.7 \%$ and 7 people who had a bad sleep quality level with a percentage of $23.3 \%$. The statistical test results obtained p-value $0.000(<0.05)$, it can be concluded that Ho is rejected so that it can be interpreted statistically there is the effect of brain exercise on the quality of sleep in the elderly.
Table 2

Distribution of Frequency of Sleep Quality in the elderly before and after being given brain exercise therapy at the Potroyudan Social Institution in Jepara in July $2020(n=30)$

\begin{tabular}{cllc}
\hline Indicators & & $\mathrm{f}$ & \multicolumn{1}{c}{$\%$} \\
\hline \multirow{2}{*}{ Before being given Brain Gym } & Good & 13 & 43.3 \\
& Bad & 17 & 56.7 \\
\hline \multirow{2}{*}{ After being given Brain Gym } & Good & 23 & 76.7 \\
& Bad & 7 & 23.3 \\
\hline $\mathrm{p}$ & & \multicolumn{2}{c}{0.000} \\
\hline
\end{tabular}

\section{DISCUSSION}

From the results of research conducted at the Potroyudan Social Institution in Jepara, based on the age characteristics of the respondents, it was found that the age of the most respondents was 66-80 years with a percentage of $68.3 \%$. This is in line with research conducted ${ }^{5}$ most of the respondents aged $60-80$ years stated that a person will experience a decrease in organ function when entering old age. This makes the elderly more susceptible to diseases such as joint pain, osteoporosis, Parkinson's and others which tend to affect poor sleep quality due to decreased physiological functions. ${ }^{6}$ The aging process will tend to experience many problems from various changes in the physiology of organs that take place over time. Also, the aging process will increase the likelihood of disease and even death. In the end, aging results in a decrease in anatomical and cellular conditions due to the metabolic buildup that occurs in the cell. In the elderly, there is a decrease in the hormone melatonin. The hormone melatonin plays a role in the hours and quality of sleep in the elderly.

From the results of the analysis of the characteristics of the gender of the respondents, it was found that the response of female was more ( $53.3 \%$ ) compared to male respondents. This is also supported by research conducted by Ismahmudi most of the respondents are female $(68.7 \%)$ who say that it is influenced by the life expectancy of female who are greater than men. more sleep disturbances occur than in men. ${ }^{7}$ Female tend to have poor sleep 
quality due to a decrease in the hormones estrogen and progesterone which have receptors in the hypothalamus. This has a direct influence on circadian rhythm and sleep patterns. Psychological conditions such as increased anxiety, anxiety, and emotions are often out of control in female due to decreased estrogen which causes sleep disturbances.

Based on the results of the Wilcoxon statistical test, it was found that the p-value was $0.000(<0.05)$.it can be concluded that Ho was rejected so that it could be interpreted statistically that there was an effect of brain exercise on the quality of sleep in the elderly with a frequency value before giving intervention that had a Good Sleep quality level. 13 people with a percentage of $43.3 \%$ and those who have a poor sleep quality level are 17 people with a percentage of $56.7 \%$. Whereas in the category after giving the intervention, there were 23 people with a good sleep quality level with a percentage of $76.7 \%$ and 7 people who had a bad sleep quality level with a percentage of $23.3 \%$.

This is in line with the results of Ismahmudi's research, where the results of Odds ratio value $=7.875$, there is $\mathrm{a}$ significant relationship between brain vitalizing exercises and the quality of sleep in the elderly. Which states that any exercise done by the elderly is proven to improve sleep disorders in the elderly. Because exercise that is done regularly will stimulate the HPA axis activity and increase 02 transport throughout the body, thereby increasing the fulfilment of sleep needs. Gymnastics for the elderly also stimulates a decrease in sympathetic nerve activity and an increase in parasympathetic activity which affects the decrease in adrenal hormones, noneprinefrin and catecholamines as well as vasodilation of blood vessels which results in oxygen transport throughout the body, especially the brain smoothly. Also, the secretion of melatonin helps fulfil sleep needs, in this condition it will improve the quality of sleep in the elderly.

This is also following the research conducted by othe research obtained the quality of sleep in the elderly after having intervened in ergonomic exercise for 8 times in 4 weeks, there was an increase in sleep quality (69.2\%) with a statistical value of $\alpha<0.05$, meaning that ergonomic exercise affected the quality of sleep in the elderly. sleep disorders. which states that there are several non-pharmacological management for the management of sleep disorders, one of which is doing daily exercise/exercise and one of them is gymnastics. Exercise can increase oxygen in the brain which will stimulate increased serotonin secretion which can make the body calm and easier to sleep which can also improve the cycle and pattern of REM and NREM sleep.

Brain therapy aims to increase blood flow to the brain, as well as stimulate the two hemispheres of the brain to work. Brain exercise can activate the brain in three dimensions, namely lateralitycommunication, focusing-understanding and centring-regulation. Light movements with a play through the hands and feet can provide stimulation or stimulus to the brain. The movement that produces this stimulus can increase cognitive abilities (alertness, concentration, speed, perception, learning, memory, solving, problems and creativity). ${ }^{8}$

Sleep quality is an important constituent of an essential part of a person's quality of life. ${ }^{9}$ Based on this understanding, sleep quality is a condition in which a person's awareness of something decreases, but the brain still works in such a way in regulating digestive function, heart and blood vessel activity and maintaining immunity, in providing energy to the body and in cognitive processes. ${ }^{10}$

The quality and quantity of sleep are strongly influenced by several factors, one of which is physical exercise, a tired person usually gets restful sleep, fatigue is the 
result of work or fun exercise. Exercising 2 hours or more before bedtime keeps the body cool and maintains fatigue that promotes relaxation. ${ }^{11}$ The aging process makes it easier for the elderly to experience sleep disorders. Elderly people often complain of three main problems in initiating and maintaining sleep.

brain gymnastics is aimed at relaxing or centring dimensions, stimulating or lateral dimensions and lightening or focusing dimensions. The concentration dimension can increase blood flow to the brain, increase oxygen reception so that it can eliminate negative thoughts, envy, jealousy, and others that can trigger stress. The lateral dimension will stimulate the coordination of the two hemispheres, namely the left and right, improve breathing, stamina, release tension, reduce fatigue, and so on. The focusing dimension to help remove focus barriers from the brain corrects inattention, lack of concentration, etc. Each dimension has a specific task so that the exercise movements that are carried out can vary. With Brain Gym movements, you can activate the neocortex and parasympathetic nerves to reduce the increase in adrenal hormone in the body which can relieve psychological and physical tension. So that the soul and body become relaxed and balanced. ${ }^{8}$

It is necessary at the time of the elderly require a factor driving because organs and physiological functions have been decreased. Sleep patterns can be improved if you do physical exercise, brain exercise or other things that make the body do activities so that the quality of the body can be better.

\section{CONCLUSION}

The results of the study can be concluded based on the characteristics of the age of the most respondents aged 66-80 years. Based on the results of the statistical test, it was found that statistically there is an effect of brain exercise on the quality of sleep of the elderly in Potroyudan social institutions in Jepara.

\section{ACKNOWLEDGMENTS}

The author realizes that without the help and encouragement of various parties, the completion of this research will not be realized. Therefore, with sincerity and humility, the authors would like to express their gratitude and highest appreciation to all respondents in this study.

\section{CONFLICTS OF INTEREST}

Neither of the authors has any conflicts of interest that would bias the findings presented here.

\section{REFERENCES}

1. Darmojo RB. Teori proses menua. dalam: Martono HH, Pranarka K, pengarang. Buku ajar boedhi-darmojo geratri. 4th ed. Jakarta: Balai penerbit fakultas kedokteran universitas indonesia; 2011. 3-12. p.

2. Claproth R. The Powerful Danger of Midbrain Activation. Jakarta: Grasindo; 2010.

3. Sharma, S. Parashar D. Effect of Resistance Training Over Aerobic Exercice in improving quality of sleep in older Adults. Indian J phystotherapy Occup Ther. 2013;7 (4),:197202.

4. PBS. Profil Lansia Provinsi Jawa Tengah 2019. Badan Pusat Statistik. 2019.

5. Oktora dwi S et al. The Effect of Murottal Al Qur'an Therapy on the Quality of Sleep of the Elderly in the Dewanata Cilacap Social Rehabilitation Unit. Soedirmaan J Nurs. 2016;11(3):168-73.

6. Azizah L. Elderly nursing. Yogyakarta: Graha I lmu; 2011.

7. Khasanah et al. Kualitas Tidur Lansia Balai Rehabilitasi Sosial "MANDIRI" Semarang. J Keperawatan Diponegoro. 2012;1(1):189-96.

8. Astuti N. Management of Insomnia at Older Age. 2015;

9. Luo et al. Prevalence and risk factors of poor sleep quality among chinese elderly in an urban community: results from the Shanghai Aging Study. 2013;

10. Sari R. The Effect of Rose Aromatherapy on Improving Sleep Quality in the Elderly. 
Muhammadiyah Universiti of Surakarta; 2015.

11. Hidayat et al. Introduction to human sleep needs. 2015. 